Air Pollution VIII (J. W. S. Longhurst, C. A. Brebbia, and H. Power, Eds., 2000, 786 pp., \$385.00, hardbound, Computational Mechanics, Inc., ISBN 185312-822-8). This extensive volume consists of papers submitted for the Eighth International Air Pollution Conference, held at Cambridge University in July 2000. The works reflect the increased understanding of air pollution episodes and the improved techniques for monitoring and modeling them. The book is divided into 13 sections: Air pollution modeling, air quality management, urban air pollution, urban and suburban transport emissions, monitoring and laboratory studies, global studies, comparison of modeling with experiments, indoor pollution, pollution engineering, fluid mechanics for environmental problems, chemistry of air pollution, aerosols and particles, and health problems.

Experimental Acoustic Inversion Methods for Exploration of the Shallow Water Environment (A. Caiti et al., Eds., 2000, 308 pp., \$127.00, hardbound, Kluwer Academic, ISBN 0-7923-6305-1). As pointed out by the editors, acoustic waves are far less attenuated in oceans than either radio waves or light waves and thus are better suited for indirect sensing. A workshop on acoustic inversion methods was held in Lisbon, Portugal, in March 1999, and 17 of the presentations are included in this volume. In these papers, received signals from either generated or natural sources were inverted to deduce properties of the internal waves, sea vegetation, ocean sediments, and the seafloor, using different mathematical procedures. This book can serve as an introduction to ocean acoustics or to oceanographers interested in recent developments in acoustics.

The Freshwater Budget of the Arctic Ocean (E. L. Lewis, Ed., 2000, 623 pp., \$208.00, hardbound, Kluwer Academic, ISBN 0-7923-6439-2). The rivers and atmosphere transport freshwater/water vapor northward into the Arctic Ocean, and returning water sinks and drives global-scale ocean currents. Because of this role in the deepwater ocean circulation and effects on climate, interest in the arctic freshwater cycle is increasing. This book includes 24 papers-presented in Tallin, Estonia, in 1998 - that describe the state of knowledge of the freshwater budget. The papers cover all aspects of the water cycle, including atmospheric moisture transport, precipitation, river flow, ice transformation, and transport within the ocean. $\mathrm{Pa}-$ pers are based on a variety of measurements, includ- ing those from oceanographic sensors, river flow meters, and radiosondes. There are also papers based on computer models. The book will be of interest to oceanographers, hydrologists, and climate modelers, as well as those interested in climate change.

Introduction to Atmospheric Chemistry (Peter V. Hobbs, 2000, 262 pp., \$24.95, paperbound, Cambridge University Press, ISBN 0-521-77800-X). This is a textbook covering the fundamentals of atmospheric chemistry, including evolution, chemical composition, radiation, clouds and precipitation, and air pollution. Intended as a companion to the author's Basic Physical Chemistry for the Atmospheric Sciences (see Bull. Amer. Meteor. Soc., 82, p. 495), it will be valuable to scholars and students in the fields of atmospheric science, environmental science, chemistry, meteorology, and geophysics. It includes 20 pages of problems for students to solve.

Climate Variability in Sixteenth Century Europe and Its Social Dimension (C. Pfister, R. Brázdil, and R. Glaser, Eds., 1999, 351 pp., \$150.00, hardbound, Kluwer Academic, ISBN 0-7923-5934-8). While weather instruments were lacking in 16th century Europe, there are many thousands of letters, diaries, chronicles, and other documents preserved in European libraries that do contain weather information. This book is an interdisciplinary effort to present a coherent picture of the climate change that occurred during that period. The first chapter presents documentary evidence, daily weather observations, and tree ring evidence. Next, the climate of 16th century Europe is reconstructed along with pressure patterns. The last chapter covers social effects, including advancing glaciers, floods, tidal flooding, grain prices, wine production, and witch hunting. The book will interest historians as well as those following climate change.

\section{TELEVISION SEALS OF APPROVAL}

$\begin{array}{lll}1187 & \text { Melissa Bell } & 2001 \\ 1188 & \text { Peter Sack } & 2001 \\ 1189 & \text { Christopher Zelman } & 2001 \\ 1190 & \text { Amellia Erck } & 2001\end{array}$

